\title{
Shoot growth and phenology modelling of grafted Stone pine (Pinus pinea L.) in Inner Spain
}

\author{
Sven MutKe, Javier Gordo, José Climent, Luis GIL* \\ U.D. Anatomía, Fisiología y Genética Forestal, ETS Ingenieros de Montes, Universidad Politécnica de Madrid, \\ Ciudad Universitaria s/n, 28040 Madrid, Spain
}

(Received 26 April 2002; accepted 13 November 2002)

\begin{abstract}
Shoot elongation, flowering phenology, branch thickening, needle and cone growth was monitored during four years in grafted stone pines in Inner Spain. The relevance of environmental influence on growth and flower regulation in Mediterranean stone pine as nut crop is stressed. Different models of thermal time compute were compared for characterizing phenostage onset, shoot and cone growth response to temperature. Non-linear regression models for relative length of preformed shoots and relative cone diameter were fitted in thermal-time scale. Shoot-growth timing was characterized by a common degree-day sum between years. Correlation of June rainfall with shoot length and flower bearing in the next year and with current needle and branch diameter growth was highly significant. Also, summer shoots and a second female flowering occurred occasionally in leader branches in dependence on June rainfall, but cone-setting failed due to the absence of pollen. Phenological model of the variation between years were consistent with observations in mature non-grafted stone pines.
\end{abstract}

stone pine (Pinus pinea) / growth and flowering phenology / phenology modelling / growing-degree-days

Résumé - Modélisation de la croissance des pousses et de la phénologie du Pin pignon greffé (Pinus pinea L.) en Espagne Centrale. L'allongement des pousses, la phénologie de la floraison, l'épaississement des branches et le développement des aiguilles et des cônes ont été suivis pendant quatre ans chez des pins pignon greffés dans une plantation située en Espagne centrale. L'influence des conditions environnementales sur la croissance et la régulation de la floraison est étudiée sur le Pin pignon méditerranéen en tant que producteur de graines. Différents modèles basés sur les sommes des températures (degrés jours) ont été comparés afin de caractériser les stades phénologiques et l'influence de la température sur la croissance des pousses et des cônes. Des modèles de régression non-linéaire ont pu être estimés reliant la longueur relative de la pousse préformée et le diamètre relatif des cônes avec l'échelle de temps thermique. La courbe de croissance des pousses est caractérisée par une même somme de degrés-jour chaque année. Une corrélation significative est établie la pluviométrie du mois de juin et la croissance des aiguilles et la croissance entre épaisseur des branches de l'année courante ou avec la longueur des pousses et la floraison portée l'année suivante. La mise en place d'une pousse estivale et d'une seconde floraison femelle peuvent se produire occasionnellement sur les branches maîtresses en relation avec les précipitations du mois de juin, cependant les cônes ne subissent aucune maturation en raison de l'absence de pollen. Des modèles phénologiques de la variation entre années concorde avec des observations réalisées sur des Pins pignons matures non greffés.

pin pignon (Pinus pinea L.) / phénologie de la croissance et de la floraison / modélisation de la phénologie / sommes des températures

\section{INTRODUCTION}

In the last decade, modelling of tree phenology has gained new attention in forest science, due to the discussion about the impact of climatic change on tree growth and forest ecosystems functioning and stability [25, 27]. Moreover, emerging functional-structural growth modelling needs a deeper view in environment-plant interaction to gain accuracy [31, 33]. Whereas traditional forest modelling methods analysed stand growth and structure using mass variables, some more recent methods for individual tree-growth models explore a more detailed representation based on the plant-architecture paradigm $[6,30,44]$. This approach focuses on inherent, geneti- cally determined topology and on quantitative laws of tree geometry $[4,42]$. To achieve environment sensibility, external influences, e.g. the relationship between annual climate parameters and growth must be taken into account [5, 47].

Air temperature is recognized as the main environment factor regulating phenological timing and growth rates in temperate plants $[7,15,47]$. Phenology dependence on temperature is related both to the amount of chilling units for budburst and to the temperature-dependent acceleration of biological processes [3, 24]. Already De Candolle quantified in 1855 this effect through the concept of thermal integral, a time-temperature product above a certain value $t_{0}$ [9]. This threshold value has been shown to vary among species and provenances [3].

\footnotetext{
* Corresponding author: lgil@montes.upm.es
} 
The relevance of temperature as a regulation factor of tree phenology in cold and temperate regions has been studied by numerous authors $[13,25]$, but this relationship is less known for Mediterranean forest species. There, water availability has been usually regarded as the main environmental factor, affecting growth amount rather than the timing of phenological events [27]. Thus, the dependence of plant phenology on temperature still must be studied also in the Mediterranean region, in order to establish accurate models [18].

Stone pine is one of the most characteristic trees of the Mediterranean flora, adapted to dry sandy or rocky soils where it forms open stands, pure or mixed with maritime pine (Pinus pinaster Ait.), some species of Juniperus or Quercus and other understorey species. Like other temperate pines, stone pine has a monopodial, cyclic growth pattern. Annual shoots, preformed in buds on the apex of last year's shoots, bear a subapical whorl of lateral buds and female strobili [32]. In stone pine, shoot elongation occurs mainly in spring; polycyclic growth is rare in grown-up trees and if present, the second growth unit is always quite shorter than the first one. Occasionally, summer shoots may bear a second female flowering. An outstanding trait of stone pine are the large cones (8-14 to $7-10 \mathrm{~cm})$ with edible seeds $(15-20 \mathrm{~mm})$ that need three years to ripen. In consequence, cones of three consecutive crops coincide in the tree each spring, when the new strobili are induced. Because of the commercial use of the edible kernels, cones are the main yield of the stonepine forests, with higher income for forest owners than timber. Actually, current breeding and improvement programs aim to the potential use of grafted stone pine as an alternative crop in specific plantations for cone yield in farmlands, but further experimentation about management techniques is still required [11, 38, 39]. Annual cone production (200-600 kg per hectare) means a biomass allocation similar to bole volume growth, which is less than $1 \mathrm{~m}^{3} /$ ha in common stonepine forests, stocking poor, excessive draining soils. Hence, reproductive structures must be taken into account in any functional-structural growth model. Additionally, physiological stress due to the xeric growth conditions may sharpen growth response to environment factors, as observed in other pine species [41]. E.g., stone pine has a strong masting habit like many Mediterranean species and yearly income from pine forests varies widely. The very irregular fruitfulness has been related to climate factors and negative autocorrelations with previous crops [20]. Thus, yield modelling with a non-sensitive approach would fail to integrate these sources of between-years variance with great biological and economic importance. On the other hand, there is no published information about the phenology of inland stonepine.

Most temperature-based phenological models published for forest species concern two singular ontogenetic events: the onset of budburst in cold and temperate climates [24, 25, 47] and the flowering, especially in seed orchards [13, 15, 35]. Fewer studies have been published about shoot growth as another aspect of ontogenetic development linked to spring temperature in pines $[2,14,23]$. Shoot elongation is not a discrete event but a continuous process observed by repeated measurements. Moreover, Mediterranean pines like Pinus pinea do not have well defined smooth winter buds, nor a clear budburst, but the stem units of their long buds "just start elon- gating" [14]. Phenological parameters are thus best derived from growth curves rather than assessed visually as discrete phenostages.

Temperature relevance for leaf expansion rate has been stressed in non-woody species at organ, tissue and cell level [22]. In roots and monocot leaves, processes involved in growth show a linear response to thermal integral because one clearly defined meristematic zone produces continuously and at constant rate new cells which subsequently elongate, whereas leaf growth in dicot species like sunflowers occurs in whole the leaf area, thus not absolute, but relative growth rate related to current size is constant in thermal time [21]. Both in monocot and dicot leaf growth, cell division and cell elongation are nearby in time and space. Sequence is quite different in preformed shoot growth of woody axes, like those in pines: in temperate climates, differentiation (activity of apical meristem) takes place during bud formation the year before and only in following spring this preformed winter bud breaks dormancy and elongate (subapical growth) [10,32]. The final length of pine shoots is determined mainly by the number of stem units and less by their mean length [23, 28, 29]. On the other hand, as shoot elongation consists in the expansion of stem units (vacuole expansion) and does not depend on meristematic activity [29], growth rate is not limited by the maximum cell division rate as leaf expansion is [22], but will be determined by the expansion rate of the individual stem unit and by the simultaneous or sequential elongation of these units. By the same reasons, the response to temperature may not be linear but sigmoid in time $[14,26]$. It may be expressed as relative growth referred to final length, in order to compare shoots with different final length (numbers of stem units).

In opposition to annual plants, detailed measurements of shoot elongation or actual temperature at individual organ level are not easy to perform in crowns of mature trees. In addition, detailed growth chamber or greenhouse experiments are normally limited by tree size and age; so most experiences have been performed on seedlings or saplings with immature growth habit $[22,23]$. In this context, the study on low grafted trees offers the possibility to observe mature shoot growth in field on an intermediate scale between physiological monitored samples in controlled environment and real growth conditions in forest stands. The main objective of the present paper is to study the timing and climate influence on shoot and needle growth, flowering and cone development of stone pine in a sample of grafted trees. Especially the response functions that link shoot elongation and cone growth to thermal time are analysed, in order to evaluate if the relation between growth rate and thermal time can explain differences in phenology between years.

\section{MATERIALS AND METHODS}

\subsection{Site description and plant material}

Field data were measured in the Meseta Norte provenance region (central Douro Basin). This sedimentary plateau at $600-900 \mathrm{~m}$ a.s.l. is the coldest and one of the driest areas of natural stonepine distribution. Actually, Inner Spain is the only native stonepine area far from coastline. Its climate is not genuine Mediterranean, but has a 
continental tendency with hot, dry summers and long, harsh winters. Average temperatures range from 10.1 to $13.5^{\circ} \mathrm{C}$ and occasional late frosts occur up until May or June and early frosts from September or October. Yearly rainfall ranges from 350 to $600 \mathrm{~mm}$ with a very irregular distribution as much between years as between seasons [43].

The plant material for this study consisted of homoplastic grafted stone pines in a clone bank, located at $4^{\circ} 20^{\prime} \mathrm{W}, 41^{\circ} 35^{\prime} \mathrm{N}$ and $890 \mathrm{~m}$ a.s.l. in Quintanilla, province of Valladolid. Average temperature is $10.1{ }^{\circ} \mathrm{C}$ and rainfall reaches $447 \mathrm{~mm}$. Scions came from high cone-yield plus trees, mass-selected within the Meseta Norte stonepine stands. The ramets were planted in 1992 in $6 \times 6 \mathrm{~m}$ setting in a gap of an aged stonepine stand, so lateral pollination guarantees cone setting. An automatic weather station within the clone bank records daily maximum and minimum temperature and rainfall. The plantation is not watered.

\subsection{Experimental design}

The sampling design was hierarchical, marking three grafts of each of the three most cone-bearing clones of the plantation and three branches in each of these nine ramets. During four years (19972000), shoot elongation and diameter growth of branches and threeyear cones were monitored, and flowering was followed in these 27 apices. Shoot and cone measurements were taken once or twice a week during the main growing period in spring and once a month in the rest of the growing season, except in 1998, with lower measuring frequencies. Total annual shoot growth was partitioned into spring shoot and terminal bud/summer shoot. Branch diameter $d_{B}$ was measured monthly at the base of last year's shoot. Pearson's productmoment correlations were used to estimate relationships between spring-shoot growth parameters. Needle growth was measured in 1997 and 2000 , while in the other two years only final needle length was computed. The influence of rainfall on shoot and needle length and cone diameter was studied by regression analysis. Average final values in the four years were regressed against rainfall amount for each period of one, two or three successive months between January and August.

Phenology of shoot and flower strobili development was assessed after a categorical scale from stage A (close winter bud) to stage $G$ (formation of new terminal bud). Analyses focused on the three most relevant to female flowering:

Stage D: on the shoot tip, strobili elongate still covered with bud scales.

Stage F: the ovuliferous scales are separated to allow the pollen grains to reach the micropyles and pollinate the ovules.

Stage G: the pollinated strobili close by swelling their scales. The vegetative shoot tip has finished its elongation and a whorl of long shoot buds is formed and topped by the new terminal bud.

Female flowering phenology was monitored counting strobili per shoot in each stage. Male flowering did not occur in the studied grafts.

Characteristic dates corresponding to fixed percentages of spring shoot and cone growth were interpolated between consecutive measurements. These dates were $T_{0.1}, T_{0.5}$ and $T_{0.9}$, corresponding to $10 \%$, $50 \%$ and $90 \%$ of the total growth. Average daily growth rate $(A D G)$ between $T_{0.1}$ and $T_{0.9}$ was calculated for each shoot and cone. The branch-diameter data were too rare to estimate characteristic dates.

The relationship between heat sums and growth for each year was examined graphically before a non-linear regression model was fitted for spring shoot length at moment $t$ with thermal time; cone growth was modelled by analogous methods, though following methodology refers only to shoots. Due to a late frost in early May 1997 that presumably damaged some shoots tip; in this year, data of six shoots and two cones with erratic growth curves after this extreme meteorological event were excluded from analysis.
During the elongation phase, the current length of each spring shoot may be expressed by the relative or standardized growth referred to final elongation, discounting the initial bud length:

$$
L(d)=L_{0}+\left(L-L_{0}\right) \times G(d)
$$

where $d$ : date [Julian days]; $L_{0}$ : winter bud length; $L(d)$ : shoot length at $d ; L$ : inal spring shoot length; $G(d)$ : accumulative form of distribution function with $G(-\infty)=0, G(\infty)=1$.

Winter bud length $L_{O}$ and final length $L$ of each shoot were actual measured data; hence fitting consisted in adjusting a growth function $G(d d)$ between 0 and 1 . Chilling request for budburst was not considered in the present study, since about 1000 hours below $7{ }^{\circ} \mathrm{C}$ occur from September until January and 2000 until March in the study area. Chilling was thus assumed widely enough for breaking bud dormancy.

As discussed before, the growth-rate dependence on temperature may be expressed rather by the use of thermal time than by calendar time as argument of function $G$. This variable can be computed by the De Candolle's definition of degree-days sum $d d$ as a rectangular daily approximation to the double integral of temperature curve $t(T)$ above threshold $t_{0}$ in time interval $[T 1 ; T 2]$ :

$$
\int_{T_{1}}^{T_{2}} \int_{t_{0}}^{t(T)} 1 \mathrm{~d} t \mathrm{~d} T
$$

when $t>t_{0}$, null else. Referred only to the temperature axis, this response is a broken-line curve, constantly null below $t_{0}$ and linearly increasing with temperature above $t_{0}$. This definition should be completed by an upper threshold, when temperature reaches its optimum and growth rate is constant in spite of further increments of $t$ (or even may decrease due to metabolism costs). This upper threshold is situated in species of temperate climate zones normally about $25-28^{\circ} \mathrm{C}$ $[3,22]$. The resulting constant/linear/constant broken line model of biological relevance of environment temperature can be substituted by a differentiable sigmoid curve, as is Sarvas' forcing unit function $F U(t)$ (Eq. (2)) $[15,24]$. The growth response between $\mathrm{FU}=0$ (no response) to $\mathrm{FU}=1$ (maximum growth rate) to daily temperature average $t$ is formalized adjusting parameter $w$ after subtracting characteristic temperature $t^{\prime}$ for which response reach half of its maximum $[14,24]$ :

$$
F U\left(t_{d}\right)=\frac{1}{1+e^{w\left(t_{d}-t^{\prime}\right)}}
$$

where $t_{d}$ : daily mean temperature at day $\mathrm{d}\left[{ }^{\circ} \mathrm{C}\right] ; t^{\prime}$ : characteristic temperature (inflexion point) $\left[{ }^{\circ} \mathrm{C}\right] ; w$ : slope parameter $\left[{ }^{\circ} \mathrm{C}^{-1}\right]$.

The FU distribution may be combined with an exponential growth curve in the so calculated FU scale, adjusting this set of two equations. But whereas simple exponential function is symmetrical to inflection point $t^{\prime}$, the observed growth pattern in stone pine was quite left skewed in both time and thermal-time scales. In those cases, recommended functions are double exponentials like Gumbel or Gompertz, which are not symmetrical in the point of inflection [19]. Since growth asymptote is standardized to the unity, a modified function with two parameters $b$ (location) and $c$ (slope) was used. Parameter $c$ was negative, so the function that fulfils the limit conditions of equation (1) is:

$$
G\left(\begin{array}{l}
d \\
\sum_{0} h u
\end{array}\right)=1-e^{-e^{\frac{-\left(\sum h u-b\right)}{c}}}
$$

where $\Sigma h u$ : daily approximation to thermal integral from starting day $d_{0}$ to date $d ; b$ : moment of maximum growth (inflexion point of cumulative distribution); $c$ : slope parameter.

For comparison of both methods, the model was fitted for forcingunits sum and also for degree-days sum as argument of $G$, the latter 


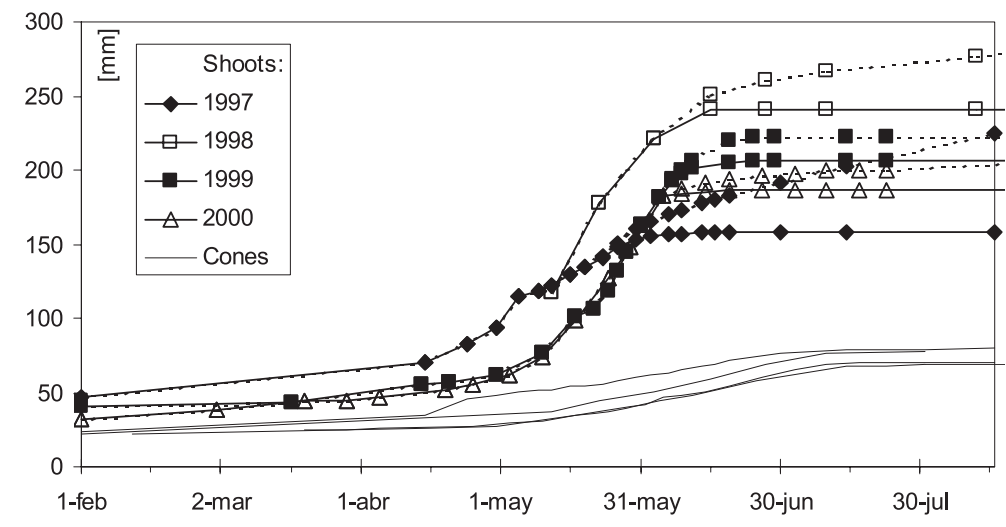

Figure 1. Average shoot elongation ( - spring shoot; - - total annual growth) and cone growth (without labels) of 27 sampled shoots in four years.
Table I. Formulae of triangular approximation to the temperature curve in one day. $\mathrm{M}$ : maximum temperature; $\mathrm{m}$ : minimum temperature measured in the day; $t_{0}$ : inferior threshold temperature of the model; $t_{s}$ : superior threshold temperature of the model $\left[{ }^{\circ} \mathrm{C}\right]$.
(1) $d d=0$
if $m<M<t_{0}<t_{s}$
(2) $d d=\frac{\left(M-t_{0}\right)^{2}}{2(M-m)}$
if $m<t_{0}<M<t_{s}$
(3) $d d=\frac{M+m}{2}-t_{0}$
if $t_{0}<m<M<t_{S}$
(4) $d d=\frac{M^{2}+m^{2}-\left(M-t_{s}\right)^{2}}{2(M-m)}-t_{0}$
if $t_{0}<m<t_{s}<M$
(5) $d d=t_{s}-t_{0}$
if $t_{0}<t s<m<M$

computed by a triangular approximation of daily thermal integral (Tab. I). Calculating the thermal-time sum uses daily maximum and minimum temperature during five or six months, so parameter calibration of the model formed by the set of two equations (heat unit amount in time and non-linear growth response to it) can not be solved using any standard mathematical optimisation procedure. Hence, model calibration was done by heuristic search comparing output of re-parameterized thermal-time model, in order to assign values to the unknown model parameters so as to maximize the models fit to data by minimizing the residual variance [40], estimated by the coefficient of variance of location parameter $b$ between years. As thermometric input was computed with $1{ }^{\circ} \mathrm{C}$ precision, parameters of the heat-sum functions were calibrated also to integers (except $w$ with 0.05 precision). In addition, this technique allows analysing the sensitivity of the response model to changes in input parameters and thus estimating its robustness. In Inner Spain, the conventional starting date $\mathrm{d}_{0}$ for thermal integral computing in horticultural phenology studies is February first (day 32 of Julian Calendar). In the studied region, this is quite earlier than visible shoot-growth initiation in stone pine, though in this month root activity recovers and it is in mid-February when resin flow starts to cover pruning wounds [37]. But as in some studies in temperate climate zones heat sum was computed from January First, these two alternative starting dates and various values for characteristic temperature $t^{\prime}(10$, $\left.12,13,14,16^{\circ} \mathrm{C}\right)$ and slope parameter $w(-0.20,-0.25,-0.30$, $-0.35^{\circ} \mathrm{C}^{-1}$ ) were used to calculate different FU amounts corresponding to each sample date, as well as amounts of degree-days for various threshold temperatures $t_{0}\left(0,1,2,3,4,5,8,12^{\circ} \mathrm{C}\right)$ with fixed superior threshold $25^{\circ} \mathrm{C}$. Since the registered daily mean temperatures in the four springs were normally below $20^{\circ} \mathrm{C}$ and never exceeded $25^{\circ} \mathrm{C}$, degree-day model fitness was affected mainly by the lower threshold, whereas accuracy of (here fixed) upper threshold estimation was secondary.
With the data of each individual spring shoot and cone growth, growth parameters $b$ and $c$ were estimated for each of these alternative thermal-time approximations as independent variable, using the DUD non-linear regression method of iterative NLIN procedure in SAS $^{\circledR}$ system [46]. Fitting each individual growth curve independently to thermal time allows obtaining individual growth parameters, in order to detect outliers previously to mingling the data in means and to study parameter distribution, correlations and differences among groups. Moreover, the inherent non-linearity of metabolic processes warns against using averages, because the non-linear function of the mean is seldom identical to the mean of the non-linear functions and may lead to bias [47]. Residual minimization of individual non-linear regression was not a valid criterion for model selection, as the consecutively measured values of the same shoot are not independent data. Moreover, most cases presented $\mathrm{R}^{2}$ above 0.95 or yet 0.99 (analogous to the linear case, $\mathrm{R}^{2}$ was computed as $1-\mathrm{SSE} /$ CSS, where SSE is the error sum of squares obtained from non-linear regression and CSS is the corrected total sum of squares for the dependent variable). So model calibration methodology consisted in three steps: (1) perform non-linear regressions for each shoot/cone growth against each thermal-integral function; (2) evaluate accuracy of these regressions by residual analysis and (3) study the distributions of parameter values in dependence on thermal-integral model and parameters and select best model and parameterization.

In the next step, analysis of variance for parameter $b$ and $c$ values were performed with clone and year as fixed effects and metric shoot/ cone variables (final length/diameter, branch diameter, number of cones, number of flowers) by GLM procedure in SAS ${ }^{\circledR}$ [46]. Fulfilling of ANOVA assumptions, especially the homogeneity of residual variances, was checked by graphic residual analysis. After checking normality of individual parameter values, great means were estimated as $95 \%$-confidence interval of means \pm 1.96 standard deviation between years.

\section{RESULTS}

\subsection{Environment influences on shoot, needle and cone growth}

Spring shoot elongation took place mainly from April to June (Fig. 1). Shoot growth was acropetal with a low growth rate in early spring and its maximum at the end of May close to the elongation stop, resulting in a left-skewed curve. In the unusually warm spring of 1997, shoot phenology was anticipated by several weeks in comparison with the other years (Figs. 1 and 2); but a night frost in May 8 damaged soft tissues of some shoot (data of six shoots were excluded from results 


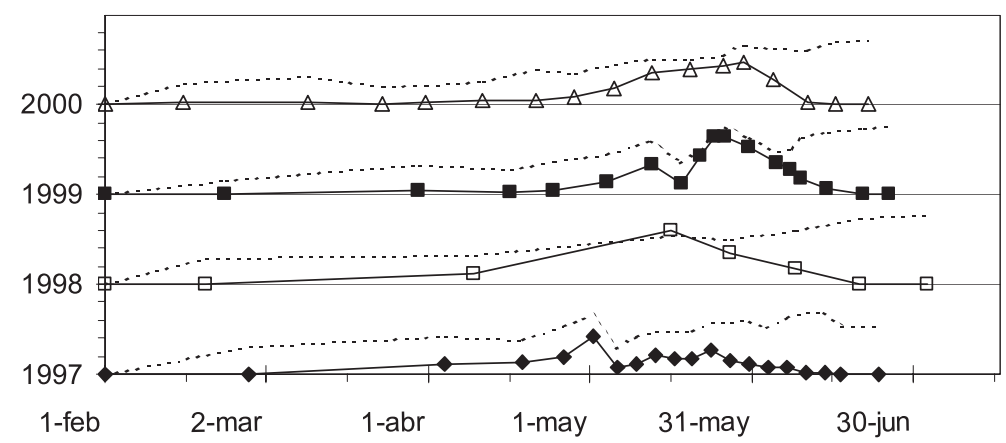

Figure 2. Current average shoot growth rate (-) of 27 sampled shoots and average temperature (- - ) in four springs. Vertical scale: 1 unit $=2 \mathrm{~mm} /$ day; 1 unit $=5^{\circ} \mathrm{C}$.

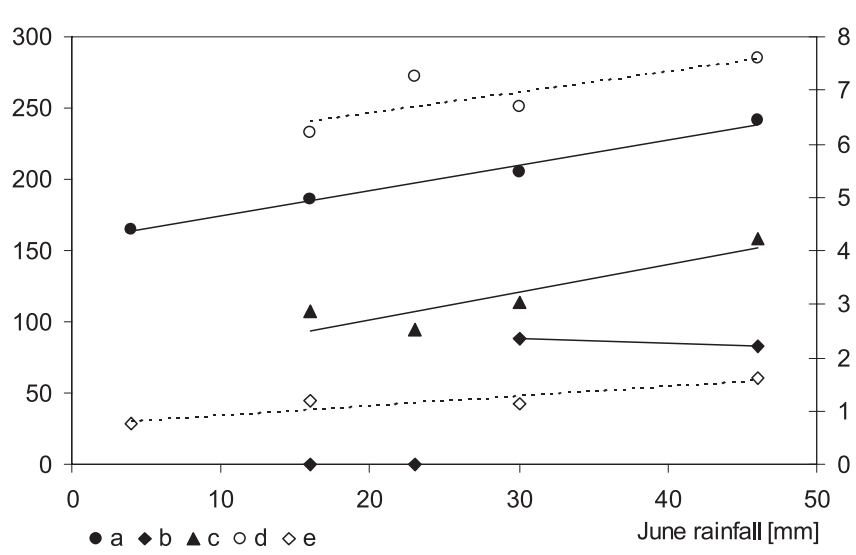

Figure 3. Tendencies of average shoot and needle length, branch thickening and flower number in dependence on rainfall during June. Left scale [mm]: a. spring shoot (next year); b. summer shoot; c. needle. Right scale: d. diameter increment [mm]; e. flowers per apex (next year)

nor are represented in the figures), and in the following cold, rainy weeks shoot growth broke down. Numerous female conelets necrotized also and aborted. On the contrary, late frosts in the other measuring years had no influence on shoot growth rate and produced no visible damage on shoots or flower buds, less developed than in 1997. In 1999, low midMay temperatures reduced shoot elongation rate, too, but growth recovered when temperatures rose (Fig. 2).

In the four measured years, June was the only period for which rainfall was positively related with average final length $L$ of spring shoots of the next year (Fig. 3). This parameter accounted for more than $99 \%$ of the variation of average spring-shoot length between the four years. The rainfall of the current growing season showed no influence on spring shoot length, but June rain seemed to determine the presence of summer shoots (lammas growth) in the same year (Fig. 3). These proleptic shoots, either partially elongated or fully developed, appeared in vigorous branches in 1997 and 1998, responding to a June rainfall above $30 \mathrm{~mm}$. Seven of the nine sampled grafts expressed summer growth. A second female flowering appeared in some of these summer shoots in July but strobili aborted because of the lack of pollen. In fall, no shoot or cone growth was observed. Average needle length and branch diameter growth showed a direct relationship with current
June rainfall (Fig. 3), although with lower coefficients of determination than those of next year's shoot length. July or August rainfall showed no effect on needle length and branch thickening, though both grew until September. Needle growth rate was nearly constant in time. The oldest ( 2 or 3 year old) needle cohorts decayed and fell in June.

\subsection{Phenology modelling}

Growth pattern of occasional lammas shoots showed no dependence on current temperature, temperature influence on growth rate was thus modelled only for preformed spring shoots and cones. In the graphic comparison of between-year coefficient of variation of shoot growth parameters (Fig. 4), only values near the optimum are represented. Ceteris paribus, starting date February First performed always better than January First. Among the tested threshold temperatures, $t_{0}=1{ }^{\circ} \mathrm{C}$ showed the lowest coefficient of variation (1.13\%) for average location parameter $b$ of shoot elongation. This value is quite similar to the value $1.15 \%$ obtained for the forcing unit function when parameters are $w=-0.2^{\circ} \mathrm{C}^{-1}, t^{\prime}=13^{\circ} \mathrm{C}$ (that is just half the distance between best linear model's thresholds $1^{\circ}$ and $25^{\circ} \mathrm{C}$ ). In fact, both curves are nearly proportional within the range $5-21^{\circ} \mathrm{C}$ (Fig. 5) and gave thus nearly the same prediction for growth curves in spring, when daily mean temperatures rarely exceeded this values. Cone growth parameter $b$ had also low coefficient of variation between the three years $(1.47 \%)$ with $t_{0}=1{ }^{\circ} \mathrm{C}$. Further results are thus shown for this common threshold, although $t_{0}=2{ }^{\circ} \mathrm{C}$ performed slightly better for cone growth prediction $(\mathrm{Cv} 1.42 \%)$. Fitted individually to thermal time above threshold $1{ }^{\circ} \mathrm{C}$, growth function (Eq. (3)) absorbed 99.38-99.998\% $\left(\mathrm{R}^{2}\right)$ of temporal variation of shoot length and 99.61-99.94\% for cone diameter even in atypical spring 1997, though residuals evidenced certain lack of fitness of the curves adjusted to cone growth (Figs. 7 and 8).

In the following (Tabs. II-IV), results are exposed only referred to degree-days sum above $1{ }^{\circ} \mathrm{C}$, whereas redundant references to FU model were omitted. The degree-day approach was preferred for two reasons. (1) The inferior threshold temperature of growth $t_{0}$ is a more intuitive concept than Sarvas' characteristic temperature $t^{\prime}$ and has a clearer biological interpretation. (2) The degree-day sum models a local linear dependence of biological processes on temperature below upper threshold, without attempting to extrapolate for higher temperatures, whereas the acceptation of the FU function, though fitted mainly with data in its central nearly linear interval, 


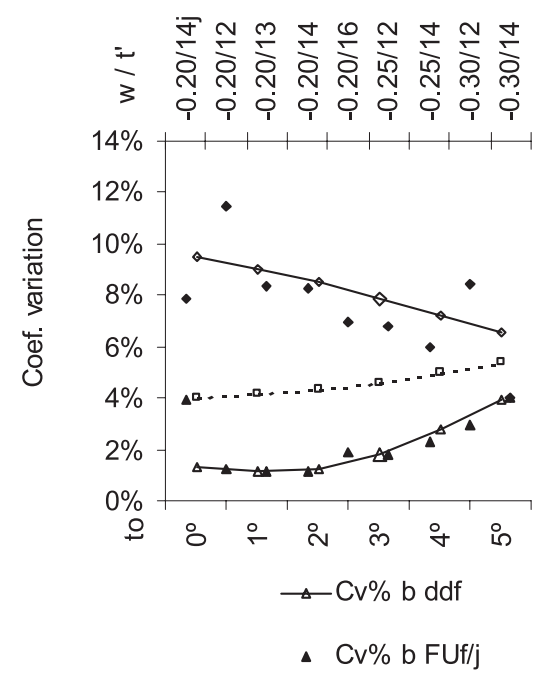

a. shoots

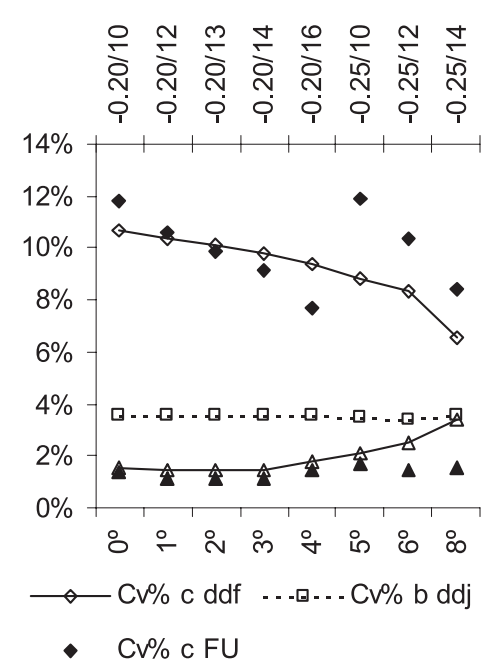

b. cones
Figure 4. Variability of Gompertz parameters $b$ and $c$ for individual shoot elongation (a) and cone growth (b) in dependence on thermal-timefunction parameters. $\mathrm{Cv} \%$ Coefficients of variation between annual means in dependence on: $d d$ : degree-days sum above threshold temperature $t_{0}\left[{ }^{\circ} \mathrm{C}\right]$ from February First (ddf) or January First (ddj) (lower axis); $w / t$ ': FU function parameters $\left[{ }^{\circ} \mathrm{C}^{-1} /{ }^{\circ} \mathrm{C}\right]$ : j: from January First, else February First (upper axis).

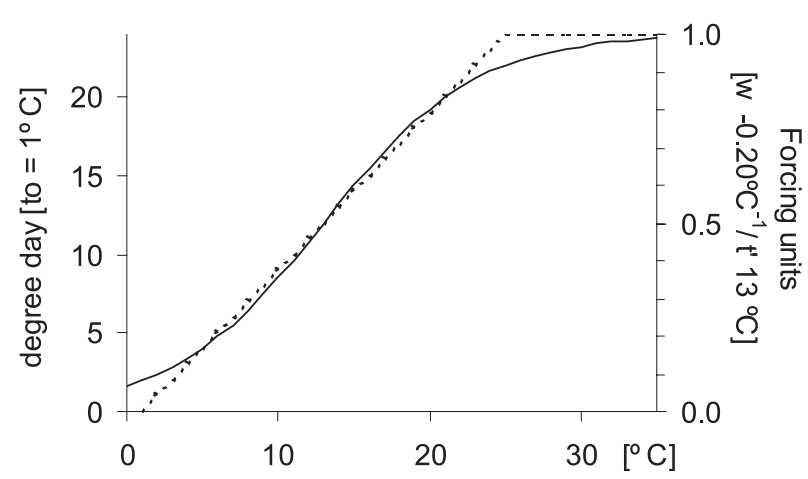

Figure 5. Best parameterisations of the two alternative thermalintegral functions. Broken line model (degree days) and sigmoid function (Forcing units).

would imply conceptually a consistent growth-rate increment up to mean temperatures of $35^{\circ} \mathrm{C}$ (Fig. 5) that is biologically fairly uncertain.

Shoot and cone growth phenology was quite similar in the four years when expressed in thermal time (Fig. 6), except in 1997 when cold May reduced somewhat the anticipated flushing. But even in this year, the rescaled shoot-growth curve is smooth and lack the dramatic breakdown observed in time scale (Fig. 1). Great mean values of the growth parameters were $b=813 \pm 18 d d$ and $c=-170 \pm 30 d d$ for spring shoots (Tab. II). Analysis of variance showed no significant effect of clone or year on shoot growth location parameter $b$, but both factors as well as their interaction influenced significantly slope parameter $c$ (Tab. III). Parameter $b$ depended also on branch diameter, $c$ on final shoot length, and parameters $b$ and $c$ were significantly correlated. Cones presented a less pronounced relative growth $(c)$ and a later maximum $(b)$ than shoots, with average values $b=1.094 \pm 32 d d$ and $c=-360 \pm$ $73 d d$. Actually, when shoot elongation was already finishing $\left(T_{0.9}\right)$, cones reached just half their size (Tab. II). Cone growth anticipated in early spring of 1997 , though it was nearly linear and coincident in the four years beyond 1000 degree days (Fig. 6). Nevertheless, both cone growth parameter $c$ and $b$ varied significantly between years and clones, also interactions and correlation between $b$ and $c$ were present, whereas final cone diameter did not influence the relative growth parameters.

Monitoring phenology in thermal time reduced the range between years for the moment of maximum shoot growth from 18 days in Julian time scale to 20 degree-days, which correspond to the heat accumulated in less than two days, this is, less than real sample frequency. For cone growth, these differences decreased from 13 days to 37 degree-days (less than 3 days) (Tab. II). The model parameterized with great mean values of $b$ and $c$ achieved to predict at each sample date in the four years current average spring-shoot length from degreedays sum, winter-bud and final shoot length means with prediction errors smaller than $25 \mathrm{~mm}$; current average cone diameter was predicted similarly with errors smaller than $10 \mathrm{~mm}$ (data not included).

Total spring shoot elongation $L$ was correlated with the actual daily growth rate $A D G$ of the shoot, but not with its growth duration $\left[d d_{0.1}, d d_{0.9}\right]$ (Tab. IV). The branch diameter had a weak correlation with reproductive competence $(N F, N C$ : number of female flowers and cones) and a negative correlation with the degree-day sums $b, d d_{0.1}, d d_{0.5}$ and $d d_{0.9}$, which were correlated with each other. Slope parameter $c$ was correlated positively with growth rate $A D G$ and growth onset $d d_{0.1}$ and negatively with growth finish $d d_{0.9}$. Cone parameters $b$ and $c$ were not correlated with parameters of bearing apex, but they were correlated with each other.

\subsection{Flower phenology}

The onset of conelet phenostage showed a direct relationship with the elongation of the bearing shoot (data not shown, average values in Tab. II). Flower bud burst (stage D) took place when half of the shoot growth had taken place and receptivity (stage F) when shoot had nearly finished elongation. The end of receptivity (stage $G$ ) occurred after shoot elongation 


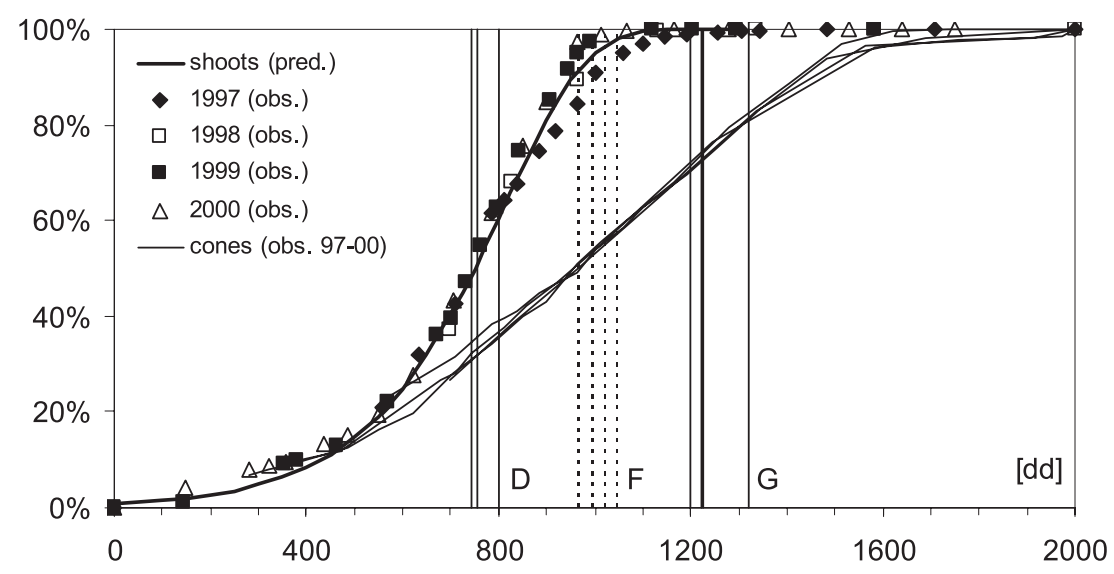

Figure 6. Predicted and observed average relative spring-shoot and cone growth in degree-day scale. Onset of female floweringstages: D - flower bud burst, F - - - receptivity; $\mathrm{G}$ - close conelets.

Table II. Average growth parameters and flowering stages in four years of 27 sampled shoots. $b$ : moment of maximal growth rate; $c$ : slope parameter; $T_{0.1}, T_{0.5}, T_{0.9}$ : degree-day sums and dates with 10, 50 and $90 \%$ of total growth, respectively; ADG: average daily growth rate; stage D: female flower-bud burst; stage F: receptivity; stage G: closed conelets.

\begin{tabular}{|c|c|c|c|c|c|c|c|c|c|}
\hline Shoot & 1997 & $(n=21)$ & 1998 & & 1999 & & 2000 & & Mean \\
\hline$b$ & $814 \mathrm{dd}$ & $5 / 10$ & $820 \mathrm{dd}$ & $5 / 22$ & $800 \mathrm{dd}$ & $5 / 28$ & $818 \mathrm{dd}$ & $5 / 27$ & $813 \pm 18 \mathrm{dd}$ \\
\hline$c$ & $-183 \mathrm{dd}$ & & $-158 \mathrm{dd}$ & & $-158 \mathrm{dd}$ & & $-186 \mathrm{dd}$ & & $-170 \pm 30 \mathrm{dd}$ \\
\hline $\mathrm{T}_{0.1}$ & $402 \mathrm{dd}$ & $3 / 31$ & $465 \mathrm{dd}$ & $4 / 13$ & $445 \mathrm{dd}$ & $4 / 27$ & $401 \mathrm{dd}$ & $4 / 13$ & $430 \pm 64 \mathrm{dd}$ \\
\hline $\mathrm{T}_{0.5}$ & $747 \mathrm{dd}$ & $5 / 3$ & $763 \mathrm{dd}$ & $5 / 18$ & $742 \mathrm{dd}$ & $5 / 24$ & $750 \mathrm{dd}$ & $5 / 21$ & $751 \pm 17 \mathrm{dd}$ \\
\hline $\mathrm{T}_{0.9}$ & $967 \mathrm{dd}$ & $5 / 24$ & $952 \mathrm{dd}$ & $6 / 2$ & $931 \mathrm{dd}$ & $6 / 6$ & $973 \mathrm{dd}$ & $6 / 6$ & $955 \pm 36 \mathrm{dd}$ \\
\hline ADG & \multicolumn{2}{|c|}{$2.4 \mathrm{~mm} /$ day } & \multicolumn{2}{|c|}{$4.0 \mathrm{~mm} /$ day } & \multicolumn{2}{|c|}{$4.3 \mathrm{~mm} /$ day } & \multicolumn{2}{|c|}{$3.2 \mathrm{~mm} /$ day } & $3.8 \mathrm{~mm} / \mathrm{d}$ \\
\hline Cone & 1997 & $(n=14)$ & 1998 & $(n=13)$ & 1999 & $(n=19)$ & 2000 & $(n=31)$ & Mean \\
\hline$b$ & $1097 \mathrm{dd}$ & $6 / 2$ & $1108 \mathrm{dd}$ & $6 / 12$ & $1071 \mathrm{dd}$ & $6 / 14$ & $1101 \mathrm{dd}$ & $6 / 15$ & $1094 \pm 32 \mathrm{dd}$ \\
\hline$c$ & $-413 \mathrm{dd}$ & & $-359 \mathrm{dd}$ & & $-332 \mathrm{dd}$ & & $-335 \mathrm{dd}$ & & $-360 \pm 73 \mathrm{dd}$ \\
\hline $\mathrm{T}_{0.1}$ & $168 \mathrm{dd}$ & $3 / 2$ & $300 \mathrm{dd}$ & $3 / 21$ & $324 \mathrm{dd}$ & $4 / 10$ & $347 \mathrm{dd}$ & $4 / 3$ & $285 \pm 157 \mathrm{dd}$ \\
\hline $\mathrm{T}_{0.5}$ & $946 \mathrm{dd}$ & $5 / 22$ & $976 \mathrm{dd}$ & $6 / 4$ & $949 \mathrm{dd}$ & $6 / 7$ & $978 \mathrm{dd}$ & $6 / 7$ & $962 \pm 34 \mathrm{dd}$ \\
\hline $\mathrm{T}_{0.9}$ & $1441 \mathrm{dd}$ & $6 / 27$ & $1407 \mathrm{dd}$ & $7 / 1$ & $1348 \mathrm{dd}$ & $7 / 2$ & $1381 \mathrm{dd}$ & $7 / 2$ & $1394 \pm 78 \mathrm{dd}$ \\
\hline Onset & 1997 & $(n=21)$ & 1998 & $(n=45)$ & 1999 & $(n=31)$ & 2000 & $(n=33)$ & Mean \\
\hline Stage D & $757 \mathrm{dd}$ & $5 / 3$ & $802 \mathrm{dd}$ & $5 / 20$ & $745 \mathrm{dd}$ & $5 / 24$ & $800 \mathrm{dd}$ & $5 / 25$ & $776 \mathrm{dd}$ \\
\hline Stage F & $1042 \mathrm{dd}$ & $5 / 29$ & $994 \mathrm{dd}$ & $6 / 5$ & $1021 \mathrm{dd}$ & $6 / 12$ & $965 \mathrm{dd}$ & $6 / 5$ & $1005 \mathrm{dd}$ \\
\hline Stage $\mathrm{G}$ & $1226 \mathrm{dd}$ & $6 / 11$ & 1319 dd & $6 / 26$ & $1223 \mathrm{dd}$ & $6 / 24$ & $1200 \mathrm{dd}$ & $6 / 21$ & $1242 \mathrm{dd}$ \\
\hline
\end{tabular}

had ceased and had no apparent relationship with other shoot events. The mean duration of stage $F$ ranged from 12 to 21 days in the four sampling years (Tab. II). Variation in stage onset was greater within than between trees or clones, so individual antesis overlapped widely (data not included). In 1997, stage D onset anticipated due to mild April weather, but cold May conditions maintained flower phenology delayed at this stage, beside frost damages already mentioned (Fig. 9).

\section{DISCUSSION}

Based on the here presented results, June showed to be an essential moment in the annual development and biomass allocation of stone pine in Inner Spain. In this month, all shoot organs (apex, needles, branch cambium, cone yields of two next years) are growing in direct competition for resources, as well as flowering is performed and next year's shoot and flowers are induced. Therefore, the observed relevance of a single environment factor, June rainfall, for all these traits, and also for the presence of lammas growth in the same summer, indicates a possibility to model accurately the environmental influence through a few key variables. Linear growth-amount dependence on rain indicates that water availability is the main limiting environment factor in the field conditions far from its saturation point. The observation that shoot length was predetermined by environment conditions during the bud formation in June of the previous year agrees with the typical fixed growth pattern in pines, where shoot length depends rather on 

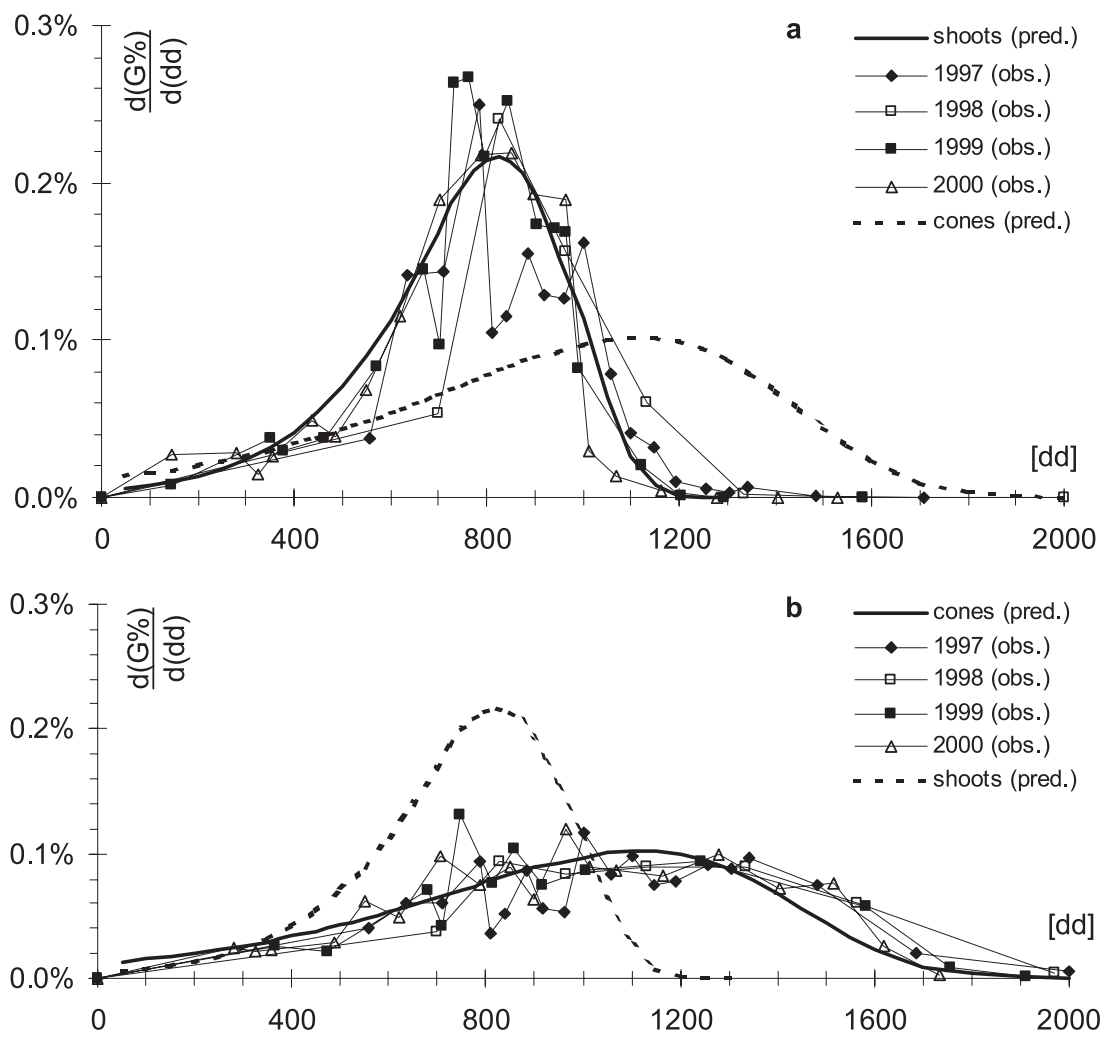

Figure 7. Predicted and observed of relative annual mean spring-shoot (a) and cone (b) growth rate [percentile increment per degree day].

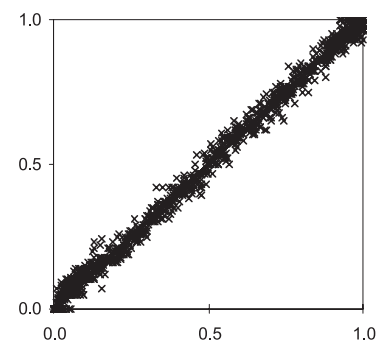

b

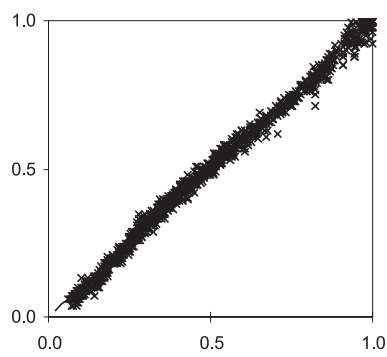

Figure 8. Observed versus predicted values by individual regression models of relative shoot (a) and cone growth (b).

the number of stem-units preformed in the bud than on their individual length [8, 14, 28, 29]. V.g., Pinus nigra Arn. in Inner Turkey has visible terminal buds in April and shows a dependence of next year's leader length on April rainfall, and no influence of current rainfall on leader length, but on needle length [26]. The number of preformed stem units in shoots of the same species depends in temperate France on rainfall in summer of bud formation [23]. In polycyclic Pinus radiata D. Don with both preformed and neo-formed growth, terminal shoot length depends on both last and current year's rainfall, needle length only on current rainfall [17]. The study of relevant growth events' regulation opens the way to go forward in the integration of (though one-year-delayed) environment sensitivity in shoot growth modelling of woody plants, in spite of the water storage and buffer function of gymnosperm xylem. However, estimation of other relevant factors, v.g. endog-

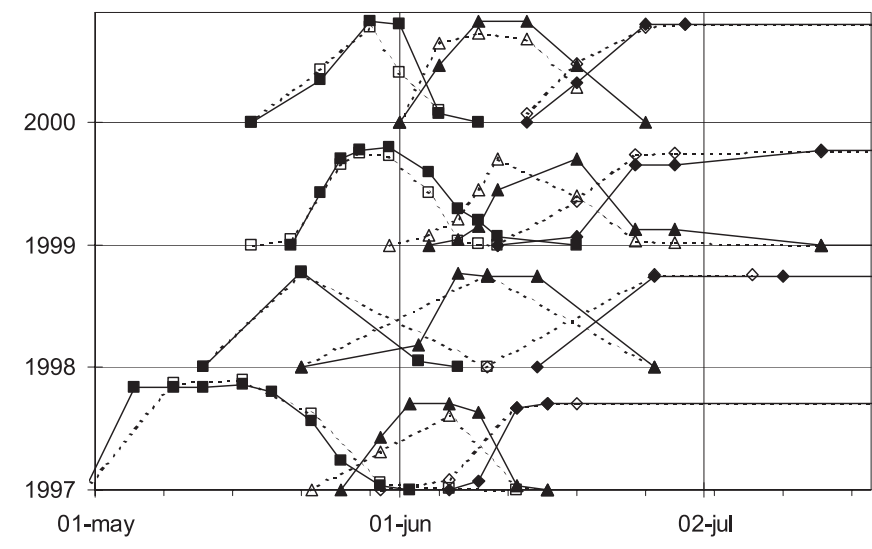

Figure 9. Phenograms of Pinus pinea female flowering 1997-2000: Proportion of flowers in consecutive stages. $\square, \square$ D: flower bud burst; $\boldsymbol{\Delta}, \triangle \mathrm{F}$ : receptivity; $\diamond, \diamond \mathrm{G}$ : close conelets $(-27$ sampled shoots (filled symbols); ---- 387 ramets (unfilled symbols)) Standardized percentages, scale omitted for clarity.

enous morphogenetic gradients like vigour decline due to meristem ageing, requires further field data from longer timeseries [44].

Environment temperature is confirmed by the established phenological model of spring-shoot and cone growth as a fairly relevant variable for phenology, at least before it surpasses upper threshold of optimal growth. As shoot elongation is based on the expansion of preformed structures, growth dependence on thermal time showed a common pattern of relative growth referred to final amount. The established model 
Table III. Analysis of variance for shoot and cone growth parameters. $b$ : moment of maximal growth rate; $c$ : growth shape parameter; $\mathrm{dB}$ : branch diameter; L: shoot length.

Shoot growth parameter $b$

\begin{tabular}{|c|c|c|c|c|}
\hline Source & SS (III type) & df & MS & \\
\hline Year & 8346 & 3 & 2782 & N.S. \\
\hline Clone & 3609 & 2 & 1805 & N.S. \\
\hline $\mathrm{dB}$ & 28206 & 1 & 28206 & $* * *$ \\
\hline$c$ & 12659 & 1 & 12659 & $* *$ \\
\hline Residuals & 143677 & 92 & 1562 & \\
\hline Total (corr.) & 205181 & 99 & & \\
\hline \multicolumn{5}{|c|}{ Shoot growth parameter $c$} \\
\hline Source & SS (III type) & df & MS & \\
\hline Year & 19550 & 3 & 6517 & $* * *$ \\
\hline Clone & 17537 & 2 & 8768 & $* * *$ \\
\hline Year $\times$ clone & 11106 & 6 & 1851 & $* *$ \\
\hline $\mathrm{L}$ & 3663 & 1 & 3663 & $*$ \\
\hline$b$ & 4567 & 1 & 4567 & $* *$ \\
\hline Residuals & 47959 & 86 & 558 & \\
\hline Total (corr.) & 102055 & 99 & & \\
\hline \multicolumn{5}{|c|}{ Cone growth parameter $b$} \\
\hline Source & SS (III type) & $\mathrm{df}$ & MS & \\
\hline Year & 16648 & 3 & 5549 & $* * *$ \\
\hline Clone & 24192 & 2 & 12096 & $* * *$ \\
\hline Year $\times$ clone & 39936 & 6 & 6656 & $* * *$ \\
\hline$c$ & 15931 & 1 & 15931 & $* * *$ \\
\hline Residuals & 51441 & 64 & 804 & \\
\hline Total (corr.) & 156897 & 76 & & \\
\hline \multicolumn{5}{|c|}{ Cone growth parameter $c$} \\
\hline Source & SS (III type) & $\mathrm{df}$ & MS & \\
\hline Year & 32308 & 3 & 10770 & $* * *$ \\
\hline Clone & 10791 & 2 & 5396 & $* * *$ \\
\hline Year $\times$ clone & 4015 & 6 & 669 & $* * *$ \\
\hline$b$ & 4659 & 1 & 4659 & $* * *$ \\
\hline Residuals & 15045 & 64 & 235 & \\
\hline Total (corr.) & 102965 & 76 & & \\
\hline
\end{tabular}

is consistent and absorbed most part of variation, even of the important deviation of the phenological calendar in an extreme year 1997. The computing of thermal integral was based on data of the weather station in the plantation, though this air temperature (measured in shadow) can be only a rough approximation to temperatures at each shoot tip, which vary widely depending on impact of direct sun radiation. The two alternatively fitted linking models between temperature and growth response gave nearly identical results and were not very sensitive to parameter calibration (Fig. 4). In fact, in case of the degree-days sum, a change of selected lower threshold will imply only a linear variation of degree-days amount as long as both daily maximum and minimum temperatures are between inferior and superior threshold, whereas changes of upper threshold do not change the heat sum at all (Tab. I).
Table IV. Pearson correlation coefficients of growth parameters for 27 shoots in 4 years. $d_{B}$ : branch diameter at base of last year's shoot. $L$ : final spring shoot length. $b, c$ : growth maximum and shape parameter. $d d_{0 . i}$ : day degrees when relative shoot elongation is $10 \cdot i \%$. NF: flower number. NC: cone number. ADG: average daily growth rate. Empty cells: not significant. * Significant at $5.0 \%$ level; $* *$ significant at $1.0 \%$ level; $* * *$ significant at $0.1 \%$ level.

\begin{tabular}{|c|c|c|c|c|c|c|c|c|}
\hline \multirow[t]{2}{*}{$d_{B}$} & 0.3969 & 0.2529 & & \multicolumn{2}{|l|}{-0.3617} & \multicolumn{3}{|c|}{$-0.2715-0.3917-0.2566$} \\
\hline & $* * *$ & $*$ & & $* * *$ & & $* *$ & $* * *$ & $* *$ \\
\hline$L$ & & & $\begin{array}{c}0.8016 \\
* * *\end{array}$ & & & & & \\
\hline$b$ & $\begin{array}{c}-0.2082 \\
*\end{array}$ & & & & & & & \\
\hline$c$ & & $\begin{array}{c}-0.2126 \\
*\end{array}$ & $\begin{array}{c}0.5921 \\
* * *\end{array}$ & $\begin{array}{c}-0.3064 \\
* *\end{array}$ & & & & \\
\hline$d d_{0.1}$ & & & $\begin{array}{c}0.5154 \\
* * *\end{array}$ & $\begin{array}{c}0.3221 \\
* * *\end{array}$ & $\begin{array}{c}0.8025 \\
* * *\end{array}$ & & & \\
\hline$d d_{0.5}$ & $\begin{array}{c}-0.2096 \\
*\end{array}$ & & & $\begin{array}{c}0.9661 \\
* * *\end{array}$ & & $\begin{array}{c}0.5555 \\
* * *\end{array}$ & & \\
\hline$d d_{0.9}$ & & & $\begin{array}{c}-0.3563 \\
* * *\end{array}$ & $\begin{array}{c}0.9035 \\
* * *\end{array}$ & $\begin{array}{c}-0.6848 \\
* * *\end{array}$ & & $\begin{array}{c}0.7623 \\
* * *\end{array}$ & \\
\hline$N=100$ & $N F$ & $N C$ & $A D G$ & $b$ & $c$ & $d d_{0.1}$ & $d d_{0.5}$ & $d d_{0.9}$ \\
\hline
\end{tabular}

On the other hand, the elongation pattern of summer shoots showed no clear dependence on current air-temperature, surpassing the upper threshold. July noon temperatures exceeded largely $30^{\circ} \mathrm{C}$, so respiration loss and water stress overcame temperature-dependent acceleration of metabolic processes. The occasionally performed polycyclic growth and flowering in the studied stone pines deviate from the normal strict monocyclic growth pattern of mature trees of the species. In the rainy summer of 1997, thirty percent of the grafts at Quintanilla exhibited lammas shoots and flowers, and so did numerous young though sexually already mature trees of the surrounding stands [37]. Neo-formed growth is a frequent capability in pine saplings and has been interpreted as a sign of shoot vigour or as ecophysiological flexibility of temperate pines with generally fixed growth pattern $[16,32,34,36]$. The dependence of summer shoot performing on June rain seems to indicate that full dormancy of terminal buds is not immediate after their formation but delays until the summer rest, if it is not skipped in favourable years by lammas growth - as in this case in 1997 , when rather short preformed spring-shoots were compensated by this additional growth.

Cone-growth response to the current air temperature was less clear than in shoot expansion. Cones showed a nearly linear development in thermal time, but the model failed to explicate differences of growth parameters $b$ and $c$ between years. This may be due to mayor cone size and woody surface that isolate cone interior from environment. On the other hand, though differences in spring shoot and cone parameters were significant between clones (except shoot's $b$ ), the differences between great means of the values of shoot and cone growth parameters $b$ and $c$ found in this study and for other 27 grafts ( 5 clones) of the clone bank sampled in 2000 were not significant (data not included in present study) [37]. In addition, a complementary flower phenostage monitoring in 387 ramets (98 clones) of the Clone Bank gave consistent results with the here studied sample during the four sampling years (Fig. 9). In 
Table V. Stonepine phenology in Inner Spain.

\begin{tabular}{|c|c|c|c|c|c|c|c|c|c|c|}
\hline & $\mathrm{J}$ & $\mathrm{F}$ & M & A & $\mathrm{M}$ & $\mathrm{J}$ & $\mathrm{J}$ & A & $\mathrm{S}$ & $\mathrm{O}$ \\
\hline Spring shoot elongation & & & & - & - & - & & & & \\
\hline Occasional summer shoot & & & & & & & 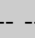 & - & & \\
\hline Secondary growth & & & & - & & & - & & & \\
\hline Needle growth & & & & & & & & - & --- & \\
\hline Flowering $(\mathrm{x}=$ pollination $)$ & & & & & & x & & & & \\
\hline 2nd year cone growth & & & & - & & & & & & \\
\hline 3rd year cone growth & & & & - & & & -- & & & \\
\hline
\end{tabular}

1999, results were contrasted with data measured in nongrafted, mature trees randomly chosen within the neighbouring stand; mean phenology (points of maximum shoot and cone growths $b$ and phenostage onsets) was not significantly different [37]. The results obtained in the sample may thus be regarded as representative for the species in this site.

Finally, phenological calendar of the studied plantation in Inner Spain (Tab. V) was compared with generical references published for another stonepine clone bank, formed by grafts of the same inland provenance, but planted in coastal lowland site in Eastern Spain with higher average temperatures (16$17^{\circ} \mathrm{C}$ ), where winter vegetative stop is there nearly absent and shoot flush takes place between March and May, pollination in March or early April [1]. In order to simulate the effect of warming (by translation of forest reproductive material to lower altitude or latitude, or by global climate change) by predictions from the established phenological model, thermal integral formula were introduced in a spreadsheet with daily thermometric register of Quintanilla between 1995 and 2001. Dates of maximum shoot growth $(b=813 d d)$ and flowering (onset stage $F=1.005 d d$ ) were estimated from fixed starting date February first for real daily maximum and minimum temperature curves in each spring and also for parallel curves 1, 2, $3,4,5$ and $6^{\circ} \mathrm{C}$ above. Simulated daily mean temperatures did not exceed in any case $23^{\circ} \mathrm{C}$ before reaching respective $b$ and $F$ dates, so no forced extrapolation above upper threshold was done. Each simulated $1{ }^{\circ} \mathrm{C}$ increment of air temperature produced in average an anticipation of one week (6.5-7.6 days), and the effect of a simulated increment of $6{ }^{\circ} \mathrm{C}$ above the actual thermic register was 38-45 days of phenological anticipation, even without forwarding the starting date of degreeday account in the soft lowland winter. These thumb-rule calculations are in concordance with observed effects of the recent climate change in Europe during the second half of 20th century on tree phenology, where advance of growth onset is estimated in 8 days due to a warming of $1{ }^{\circ} \mathrm{C}$ in early spring [12]. Thermal-time differences can explain thus the order of magnitudes of the phenological delay between coastal and inner Spain, though better external data would be needed for accurate model validation.

The mean temperature increment due to climate change is predicted for the Iberian Peninsula in $4-7^{\circ} \mathrm{C}$ during 21 st century by different scenarios [45], hence important phenological and ecological changes may derivate. An anticipated phenology of stone pine may increment the risk of late-frost injury in growing tissues, as occurred in 1997. On the other hand, more uncertainty exists about the long-term tendency of rainfall, although actual reduction of the shoot length preformed in dry years indicates that stone pine is already at present on the borders of water deficit.

Highlighting the practical applications of the present paper for the management of grafted plantations, the modelled phenology response to thermal time can provide accurate predictions of growth and flowering in a certain advance. This allows to program cultural operations like scion-collection or controlled pollinations based on automatically registered meteorological data, reducing the time-wasting direct phenological monitoring in field. The observed dependence on June rain confirms the accuracy of rainfall as a surrogate of plant water availability in environment-sensitive growth and yield models. Furthermore, it may provide a practical and cheap way to increase leaf area and cone yield through a single watering in that season in grafted plantations.

Acknowledgements: This study has been carried out within the frame of the Genetic Improvement Programme of Pinus pinea, funded by the regional government of Castile-Leon. We thank two anonymous referees for their comments that helped to strengthen considerably the original paper. Patrick Heuret kindly translated the abstract to French. First author's contribution is supported by a FPU scholarship from MECD (Spanish Ministry of Education and Culture).

\section{REFERENCES}

[1] Abellanas B., Pardos J.A., Seasonal development of female strobilus of stone pine (Pinus pinea L.), Ann. Sci. For. 46 (1989) 51-53.

[2] Alía R., Gómez A., Agúndez M.D., Bueno M.A., Notivol E., Levels of genetic differentiation in Pinus halepensis Mill. in Spain using quantitative traits, isozymes, RAPDs and cp-microsatellites, in: Müller-Starck G., Schubert R. (Eds.): Genetic Response of Forest Systems to Changing Environmental Conditions, Vol. 70, Forestry Sciences, Kluwer Academic Publishers, Dordrecht, 2001, pp. 151160 .

[3] Baldini E., Arboricultura general, Mundi-Prensa, Madrid, 1992.

[4] Barthélémy D., Blaise F., Fourcaud T., Nicolini E., Modélisation et simulation de l'architecture des arbres : Bilan et perspectives, Rev. For. Fr. XLVII nº sp. (1995) 71-96.

[5] Bouchon J., Présentation de l'Action d'Intervention sur Programme sur l'architecture des arbres fruitiers et forestiers, in: Bouchon J. (Ed.), Architecture des arbres fruitiers et forestiers, Montpellier (France), 23-25 novembre 1993, Les Colloques no 74, INRA Editions, Paris, 1995, pp. 7-16.

[6] Bouchon J., Houllier F., Une brève histoire de la modélisation de la production des peuplements forestiers: place des méthodes architecturales, in: Bouchon J. (Ed.), Architecture des arbres fruitiers et forestiers. Montpellier (France), 23-25 novembre 1993, Les Colloques n ${ }^{\circ} 74$, INRA Éditions, Paris, 1995, pp. 17-25.

[7] Burczyk J., Chalupka W., Flowering and cone production variability and its effects on parental balance in a Scots pine clonal seed orchard, Ann. Sci. For. 54 (1997) 129-144.

[8] Cannell M.G.R., Thompson S., Lines R., An analysis of inherent differences in shoot growth within some northern temperate conifers, in: Cannell M.G.R., Last F.T. (Eds.), Tree physiology and yield improvement, Academic Press, New York, 1976, pp. 173205.

[9] Cara J.A. de, Gallego T., Gómez M., Agrometeorología 1997/98, in: Calendario meteorológico 1999, Instituto Nacional de Meteorología, Madrid, 1998, pp. 113-127. 
[10] Caraglio Y., Barthélémy D., Revue critique des termes relatifs à la croissance et à la ramification des tiges des végétaux vasculaires, in: Bouchon J., de Reffye Ph., Barthélémy D. (Eds.), Modélisation et simulation de l'architecture des végétaux, INRA, Paris, 1997, pp. 11-87.

[11] Catalán G., Current Situation and Prospects of the Stonepine as Nut Producer, FAO - Nucis-Newsletter 7 (1998) 28-32.

[12] Chmielewski F.M., Rötzer Th., Response of tree phenology to climate change across Europe, Agric. For. Meteorol. 108 (2001) 101-112.

[13] Chuine I., Cour P., Rousseau D.D., Selecting models to predict the timing of flowering of temperate trees: implications for tree phenology modelling, Plant Cell Environ. 22 (1999) 1-13.

[14] Chuine I., Aitken S.N., Ying C.C., Temperature thresholds of shoot elongation in provenance of Pinus contorta, Can. J. For. Res. 31 (2001) 1444-1455.

[15] Chung M.S., Flowering Characteristics of Pinus sylvestris L. with Special Emphasis on the Reproductive Adaptation to Local Temperature Factor, Acta Forestalia Fennica 169 (1981) 5-68.

[16] Coudurier T., Barthélémy D., Chanson B., Courdier F., Loup C., Modélisation de l'architecture du Pin maritime Pinus pinaster Ait. (Pinaceae) : Premiers résultats, in: Bouchon J. (Ed.), Architecture des arbres fruitiers et forestiers. Montpellier (France), 23-25 novembre 1993, Les Colloques nº 74, INRA Éditions, Paris, 1995, pp. 305-321.

[17] Cremer K.W., Relations between reproductive growth and vegetative growth of Pinus radiata, For. Ecol. Manage. 52 (1992) 179-199.

[18] Desprez-Loustau M.L., Dupuis F., Variation in the phenology of shoot elongation between geographic provenances of maritime pine (Pinus pinaster) - implications for the synchrony with phenology of the twisting rust fungus Melampsora pinitorca, Ann. Sci. For. 51 (1994) 553-568.

[19] Draper N.R., Smith H., Applied Regression Analysis, John Wiley \& Sons, New York, 1980.

[20] Gordo J., Mutke S., Gil L., La producción de piña de Pinus pinea L. en los montes públicos de la provincia de Valladolid. in: Primer Simposio del Pino Piñonero (Pinus pinea L.) (II) Valladolid, 2000, pp. 269-278.

[21] Granier C., Tardieu F., Spatial and Temporal Analyses of Expansion and Cell Cycle in Sunflower Leaves, Plant Physiol. 116 (1998) 991-1001.

[22] Granier C., Tardieu F., Is thermal time adequate for expressing the effects of temperature on sunflower leaf development? Plant Cell Environ. 21 (1998) 695-703.

[23] Guyon J.P., Influence du climat sur l'expression des composantes de la croissance en hauteur chez le pin noir d'Autriche (Pinus nigra Arn. ssp. nigricans), Ann. Sci. For. 43 (1986) 207-226.

[24] Hänninen H., Modelling bud dormancy release in trees from cool and temperate regions, Acta Forestalia Fennica 213 (1990) 1-47.

[25] Hänninen H., Effects of climatic change on trees from cool and temperate regions: an ecophysiological approach to modelling of bud burst phenology, Can. J. Bot. 73 (1995) 183-199.

[26] Isik K., Seasonal course of height and needle growth in Pinus nigra grown in summer-dry Central Anatolia, For. Ecol. Manage. 35 (1990) 261-270.

[27] Kramer K., Leionen I., Loustau D., The importance of phenology for the evaluation of impact of climate change on growth of boreal, temperate and Mediterranean forest ecosystems: an overview, Int. J. Biometereol. 44 (2000) 67-75.

[28] Kremer A., Component Analysis of Height Growth, Compensation between Components and Seasonal Stability of Shoot Elongation in Maritime Pine (Pinus pinaster Ait.), in: Proceedings of IUFRO Conference on Crop Physiology of Forest Trees, Helsinki, 1984.
[29] Kremer A., Décomposition de la croissance en hauteur du pin maritime (Pinus pinaster Ait.): architecture génétique et application à la sélection précoce, Thèse de Doctorat, Université de Paris XI, Centre d'Orsay, 1992.

[30] Kurth W., Die Simulation der Baumarchitektur mit Wachstumsgrammatiken. Stochastische, sensitive L-Systeme als formale Basis für dynamische, morphologische Modelle der Verzweigungsstruktur von Gehölzen. Wissenschaftlicher Verlag Berlin, Berlin, 1999.

[31] Kurth W., Sloboda B., Growth grammars simulating trees - an extension of L-systems incorporating local variables and sensitivity, Silva Fenn. 31 (1997) 285-295.

[32] Lanner R.M., Patterns of shoot development in Pinus and their relationship to growth potential, in: Cannel M.G.R., Last F.T. (Eds.), Tree physiology and yield improvement, Academic Press, New York, 1976.

[33] Le Roux X., Sinoquet H., Foreword 2nd International Workshop of Functional-Structural Tree Models, Ann. For. Sci. 57 (2000) 393394.

[34] Loup C., La variabilité architecturale chez le Pin d'Alep Pinus halepensis Mill., in: Architecture, structure, mécanique de l'arbre, Sixième Séminaire Interne, Laboratoire de mécanique et de génie civil, Université de Montpellier II, 1993, pp 4-16.

[35] Matziris D.I., Genetic Variation in the Phenology of Flowering in Black Pine, Silvae Genet. 43 (1994) 321-328.

[36] Meredieu C., Croissance et branchaison du Pin laricio (Pinus nigra Arnold ssp. laricio (Poiret) Maire) : Élaboration et évaluation d'un système de modèles pur la prévision de caractéristiques des arbres et du bois, thèse de Doctorat, Université Claude Bernard-Lyon I, 1998.

[37] Mutke S., Fenología de Pinus pinea L. en un Banco Clonal (Valladolid), MSc dissertation, Universidad de Valladolid, 2000.

[38] Mutke S., Díaz-Balteiro L., Gordo J., Análisis comparativo de la rentabilidad comercial privada de plantaciones de Pinus pinea $\mathrm{L}$. en tierras agrarias de la provincia de Valladolid, Investig. Agrar. Sist. Recur. For. 9 (2000) 269-303.

[39] Mutke S., Gordo J., Gil L., The Stone Pine (Pinus pinea L.) Breeding Programme In Castile-Leon (Central Spain), FAOCIHEAM NUCIS-Newsletter 9 (2000) 50-55.

[40] Openshaw S., Openshaw C., Artificial Intelligence in Geography, J. Wiley and Sons, Chichester, 1997.

[41] Parker A.J., Parker K.C., Faust T.D., Fuller M.M., The effects of climatic variability on radial growth of two varieties of sand pine (Pinus clausa) in Florida, USA, Ann. For. Sci. 58 (2001) 333-350.

[42] Perttunen J., Sievänen R., Nikinmaa E., Salminen H., Saarenmaa H., Väkevä J., LIGNUM: A tree model based on simple structural units, Ann. Bot. 77 (1996) 87-98.

[43] Prada M.A., Gordo J., de Miguel J., Mutke S., Catalán G., Iglesias S., Gil L., Las regiones de procedencia de Pinus pinea L. en España, Organismo Autónomo de Parques Naturales, Madrid, 1997.

[44] Reffye Ph. de, Dinouard P., Barthélémy D., Modélisation et simulation de l'architecture de l'orme du Japon Zelkova serrata (Thunb.) Makino (Ulmaceae) : La notion d'axe de référence, in: Edelin C. (Ed.), L'arbre. Biologie et Développement, Naturalia Monspeliensa $\mathrm{n}^{\circ}$ h.s., 1991, pp. 251-266.

[45] Santos F.D., Forbes K., Moita R. (Eds.), Mudança Climática em Portugal. Cenarios, Impactes e Medidas de Adaptação - SIAM. Sumário Executivo e Conclusões, Gradivia, Lisboa, 2001.

[46] SAS Inc., SAS-STAT User's Manual, Ver. 6.0, SAS Inc., 1996.

[47] Schwalm C., Ek A.R., Climate change and site: relevant mechanisms and modelling techniques, For. Ecol. Manage. 150 (2001) 241-257. 